\title{
Pervasiveness of Poverty among People Living with HIV/AIDS in South Eastern Nigeria
}

\author{
J. O. Ezeokana*, O.A. U. Nnedum*, and S. N. Madu** \\ *Department of Psychology, Nnamdi Azikiwe University, Awka, Nigeria \\ **Department of Psychology, University of Limpopo, South Africa
}

KEYWORDS Poverty. PLWHA. HIV/AIDS Disease. Igbo People. South Eastern Nigeria. Africa

\begin{abstract}
The purpose of this study was to examines the pervasiveness of poverty among people living with HIV/ AIDS (PLWHA) in south eastern Nigeria. A total of 154 Igbo people residing in South Eastern Nigeria made up of $50 \%$ people living with HIV/AIDS and 50\% medically diagnosed HIV-negative individuals participated in a study that tested three hypotheses. Results indicated that a statistically significant difference was found between PLWHA and those that were not, regarding poor standard of living, with $\mathrm{F}(1,153)=23.67, \mathrm{p}<.000$; poverty, with $\mathrm{F}(1,153)=05.76$, $\mathrm{p}<.004$; but not with household poverty, with $\mathrm{F}(1,153)=.772, \mathrm{p}<.487$ as predicted. Socio-economic index of poverty (Nnedum, 2006) was used to access individuals' poverty status. The results supported all the three hypotheses. The result suggests that Poverty is a prevalent issue among people living with HIV/AIDS in south eastern Nigeria. Reducing poverty is a viable pre-requisite in both stemming the epidemic and providing adequate care and support to those affected with HIV/AIDS disease?
\end{abstract}

\section{INTRODUCTION}

The human immunodeficiency virus /acquired immunodeficiency syndrome (HIV/AIDS) is currently the most devastating and contagious disease of the century. Empirical evidence (Hawkes and Ruel 2006 ; Chacham et al. 2007 ; Cluver and Gardner 2007 ; Foster 2007 ; Kaiser Family 2007 ; Nosyk et al. 2007 ; Smith 2007 ) suggests that HIV/ AIDS is a disease of poverty. Similarly, several studies on HIV/AIDS in South Eastern region of Nigeria (Smith 2001; Smith 2002; Nnedum 2006; Ezeokana and Nnedum 2007; Smith 2007) suggest that economic hardship occasioned by abject poverty is at the province of PLWHA. On the contrary, some studies (Norr et al. 1996; Gilmore et al. 1997) suggest that HIV is a behavioral illness that has less to do with economic characteristics.

In the literature, Castro et al. (1998) using one-hundred-and-thirteen in -depth interviews in two economically marginalized but contrasting communities involving a study of AIDS-related illness trajectories in Mexico, found that prevailing poverty condition is linked to HIV spread. There are probably two streams of research linking HIV spread to poverty. The first

Contact Address:

Dr. S. N. Madu, Professor,

Department of Psychology, University of Limpopo,

Turfloop Campus, Private Bag X1106, Sovenga 0727,

South Africa

Telephone/Fax: +27-15-2682318,

E-mail:madus@ul.ac.za stream of research studies (Rennie and Behets 2006; Weidle et al. 2006; Nosyk et al. 2007; Smith, 2007) suggest that the background poverty of individuals causes, sustains and propagates the spread of HIV/AIDS disease. The second stream of research studies (Hawkes and Ruel 2005 ; Chancham et al. 2007; Foster 2007; Mendenhall et al. 2007) Proposes to the contrary that, it is the nature or condition of HIV/AIDS disease that lure the afflicted patients with HIV/AIDS to various poverty conditions. The HIV/AIDS disease has reached endemic proportions in some parts of Sub- Saharan Africa and there is a shift towards lower income, unskilled, poor, people being the worst victims (Williams and Ray 1993). Researches show the importance of recognizing that HIV/AIDS transmission is also influenced by a web of complex economic psychology factors that shape understanding of HIV disease (Brown et al. 2001; Bond et al. 2002); such economic Psychology factor like poverty may be of particular importance to researchers, governments and humanitarian agencies.

\section{Epidemiology of HIV/AIDS in Nigeria}

In Nigeria, the first reported case of HIV/AIDS occurred in 1986 (Bureau of Global Health 2003). Since this date, the number of cases in Nigeria has seen a "steady rise of $1.8 \%$ in $1993,3.8 \%$ in $1994,4.5 \%$ in 1996, and about $5.4 \%$ in 1999" (HIV/ AIDS Emergency Action Plan [HEAP] 2001). 
Currently, Nigeria has the largest number of adult HIV/AIDS cases in West Africa, accounting for "11 percent of all infections worldwide" (Bureau of Global Health 2003).

The HIV/AIDS Emergency Action Plan [HEAP] (February 2001), however reported that Nigeria has a prevalence rate of over $05 \%$, placing it "in the explosive phase of the epidemic with potentially grave consequences" (p.1). UNAIDS reported that 3.5 million Nigerians were living with HIV/AIDS in December 2001, and the organization estimated that the figure would be between 3.5 to 4 million by the end of 2002 (www.usaid.gov). In 2003, the reported figure was 3.6 million (UNAIDS 2004). In a surveillance study completed by the Bureau of Global Health (2001), the prevalence rate of HIV in Nigeria was shown to have increased steadily not only in the general population, but also among several at - risk groups. For example, the number of HIV - positive cases among sex workers in Lagos has shown a steady increase. In $1988-89,2 \%$ of sex workers tested positive; and from 1990 to $1991,12 \%$ of sex workers tested positive; and from 1993-1994, 30\% of sex workers tested positive. In addition, in 2000 , the median rate of HIV occurrence among patients seeking treatment for sexually transmitted infections in 10 states was $11.5 \%$. Among patients diagnosed with tuberculosis, the median HIV prevalence rate for the 10 states was $17 \%$ and the range was $4.2 \%$ through $35.1 \%$.

The highest prevalence rates correspond to the most active sex groups; 20 - 24 years olds at $5.6 \%, 25-29$ year olds $5.4 \%$, and $15-19$ year olds at $4.0 \%$. The prevalence rate decreases with age: $30-49$ year olds have a $3.2 \%$ rate (Human Development Report, Nigeria, p.22). Of the total population infected in Nigeria, $60 \%$ are young people below 25 years, and $54 \%$ of all adult infections are women. Moreover, women are infected at a younger age than men. More than half of those with HIV/AIDS in Nigeria are women and children. About 290, 000 children (aged 0 15) and 1.9 million women (ages 15-49) in Nigeria lived with the AIDS virus at the end of 2003 (UNAIDS 2004). Many died. In 2002 the AIDS related death in the country ranged from 200,000 to 310, 000 (Bureau of Global Health 2003 ; UNAIDS 2004).

\section{HIV/AIDS and Poverty in Nigeria}

Nigeria has the third highest number of people estimated to be living with HIV/AIDS in the world after South Africa and India (Kaiser Family 2003). The National HIV Sero-prevalence Sentinel Survey (Federal Ministry of Health 2004) estimated that about $70 \%$ of Nigerians are poor. The Human Development Report (2000) ranked Nigeria at 151 out of 174 countries and among the poorest 20 countries in the world. The Gross Domestic Product growth rate of Nigeria in 1999 was $2.7 \%$ while the income per capita in the same year was \$350 (Three Hundred and Fifty U.S. Dollars) only. Nigeria has the second highest number of people living with HIV/AIDS in SubSaharan Africa, and the highest number in West Africa (Kaiser Family 2006). There is a relationship between AIDS as disease of poverty in the economic context, particularly in relation to global economic development, urbanization, homelessness and the disintegration of neighborhood, migration and systems of labour and production. Chronic unemployment in Nigeria and modern economic constraints and demands now make it difficult for extended families, the cherished African safety net, to honour their responsibilities and obligation to their kinsmen and kinswomen. Poverty has created a breeding ground for HIV/ AIDS pandemic in Nigeria (Nnedum 2006).

\section{Prevalence of HIV/AIDS in Sub - Saharan Africa}

Sub-Saharan Africa has just over $10 \%$ of the world's population but is home to more than $60 \%$ of all people living with HIV/AIDS. The number of people infected with the AIDS virus in sub Saharan Africa totaled 28. 4 million (UNAIDS 2004). In 2004, an estimated 2.7 million - 3.8 million people in the region became infected, while 2.1 million to 2.6 million died of AIDS (UNAIDS 2004). Among young people aged $15-25$ years, an estimated $6.3-8.3 \%$ of women and $2.0-2.7 \%$ of men were living with HIV at the end of 2004 (UNAIDS 2004). Young people ages 15 through 24 accounts for almost half of the new HIV infections worldwide, with more than 6, 000 contracting the virus everyday (UNAIDS 2004). Since 1981, about 38 million people have lived with the AIDS virus, and "since 1993, the number of people infected with HIV/AIDS in sub Saharan Africa has tripled to 28 million". Women account for nearly $50 \%$ of the population living with HIV worldwide, and $57 \%$ of all women with HIV reside in sub - Saharan Africa (UNAIDS 
2004). Furthermore, UNAIDS attributed the deaths of more than 17 million people in sub - Saharan Africa since 1993 to AIDS related infections. Adults HIV prevalence has been roughly stable in recent years. But stabilization does not necessarily mean the epidemic is slowing. On the contrary, it can disguise the worst phase of an epidemic, when roughly equal number of people are being newly infected with HIV as are dying of AIDS (UNAIDS 2004). Nearly 800, 000 children were infected with HIV in 2002, mostly through their mothers either during childbirth or through breastfeeding. Currently, 1.3 million children are living with the disease. Since the onset of the epidemic, the death toll among children under age 15 has risen to 5.3 million (UNAIDS 2004). Some 3.5 million adults and 500, 000 children died of AIDS during the course of 2002. Roughly the same number of HIV infections developed into symptomatic AIDS. HIV has more than doubled the adult death rate in some places, and is the single biggest cause of adult death in Sub Saharan Africa (UNAIDS 2004). Indeed HIV/ AIDS is among the top ten killers worldwide, and given the current levels of HIV infection in Sub Saharan Africa, it has moved into the top five, overtaking such well - established causes of death as malaria, tuberculosis and diarrhea in many countries (UNAIDS 2004).

\section{Poverty and HIV/AIDS Scourge in Nigeria}

Several studies have linked poverty to the spread of the AIDS virus in both developed and developing countries (Barnett and Whiteside 2002; Lazzarini 2002 ; Bureau of Global Health 2003; Catholic Agency for Overseas development [CAFOD] 2003). Lazzarini pointed out, "in the period from 1988 through 1999, rates of death from AIDS were consistently associated with poverty; the lower the income for a country, the higher the rate of death" (p. 2). Stillwaggon (2001) warned that AIDS leads to national poverty, predicting that not treating the AIDS virus will lead to the "early death of 25-35 percent of the work force in the next decade" (p. 2). The Nigerian economy has witnessed negative growth in the last two decades. Oil revenues represent 95 percent of the country's' exports but account for 40 percent of the GDP and 70 per cent of budget revenue (Human Development Report, Nigeria 2004). Nigeria has, until recently, a huge external debt of US $\$ 28.5$ billion, representing four times the federal allocation to education and about 12 times the allocation to health (p. 32). The deterioration and subsequent decline of health services, education and other social services means a loss of opportunities for the prevention of HIV. Similarly, reduced provision of quality health services also represents a loss of opportunities to control other Sexually transmitted illnesses (STIs). The report stated that poverty increases vulnerability to HIV and other STIs. Under conditions of grinding poverty, the risk of HIV assumes a lower priority among people's daily concerns. People in such circumstances are more concerned about the immediate consequences of survival than the chances of contracting a virus whose effects do not manifest immediately. The poor lack recreational facilities and often sex becomes the means for passing time (P.32). Poverty may also drive women into trading sex for money, food and other goods. Poor people migrate from rural areas to urban settings in search of jobs, leaving their closely-knit family settings for an environment where sexual risk takings are higher than in their rural home areas (p.33).

Indeed, it has been argued that poverty is the greatest single facilitator of HIV transmission in Nigeria. The report pointed out "not only is poverty observable at the individual, family, local, and national levels, it has become a national culture and the chief index for measuring the degree of the nation's under-development".

Loss of so many in the work force, especially young workers, has a huge economic impact. Bjorkman observed that the effect of the AIDS disease is immense because the disease is affecting young adults (2002). It is robbing families, communities, and nations of their most productive people. Furthermore, as families lose their caretakers and earners, "income is lost, agriculture output declines, nutrition worsens, spending on health care increases, funeral costs soar, savings turn into debts, children drop out of school" (p.6). In Nigeria many of the foods that are known to supply essential vitamins and nutrients are priced beyond the reach of the average income-earner. Meanwhile, the breadwinners of a sizeable chunk of expectant families are either unemployed or underemployed.

Although, as Lazzarini pointed out, poverty may be a factor in the spread of the AIDS virus (2002), Takahashi observed that AIDS leads to poverty (1998). PLWHAs are poor because they are unemployed, live in substandard housing, and 
can obtain only poor healthcare. It appears that poverty may both contribute to the spread of AIDS and result from that spread: "Conditions of poverty create circumstances that make people more vulnerable to HIV and drastically worsen the conditions of people already infected. Conversely, HIV increases the degree of poverty for the families and communities infected and affected" (CAFOD 2003, p 1: UNAIDS 2004). Increase in poverty resulting from HIV/AIDS has been documented. In a study of rural Thailand, farm output and household income increased from $52 \%$ to $67 \%$ in households of people infected with the AIDS virus (Bjorkman 2002). Similarly, in a study of Zambians conducted by Bjorkman, two thirds of urban households who lost their breadwinner to AIDS were found to have experienced an $80 \%$ loss in income. Fourie and Schonteich described the broad relationship between poverty and HIV/AIDS (2001). They suggested that two factors control the degree of susceptibility and vulnerability of a society to the disease: "the level and distribution of wealth and income, and the degree of social cohesion" (pp. 2-3). The authors pointed out that HIV/AIDS affects the quality of life and the day-to-day living not only of the people infected with the AIDS virus, but also of their families and their larger society. Spouses incur increased absenteeism in their places of work, children drop out of school, productivity diminishes, and the economy suffers immensely.

\section{METHODS}

\section{Demographics of Participants}

The participants of this research were adults who resided in the Southeastern Region of Nigeria. The questionnaires were distributed to two hundred adults and all the participants returned back the questionnaires. Of the two hundred participants, seventy-seven respondents endorsed HIV/AIDS status. Of those who did not endorse the HIV/AIDS status, through random sampling, seventy-seven questionnaires were selected. The purpose of the random sampling is to allow for more effective statistical analysis and comparisons following the research hypotheses.

The mean age of the 154 participants was 31.23 years, with a standard deviation of 9.114 (Table 1). Regarding religious orientation, 149
Table 1: Age of the 154 participants

\begin{tabular}{lcc}
\hline Variable & $X$ & $S D$ \\
\hline Age & 31.23 & 9.114 \\
\hline
\end{tabular}

(96.8\%) identified themselves as Christians, 3 (1.9\%) identified themselves as Muslims, 1 (0.6\%) identified themselves as following the African traditional religion, and $1(0.6 \%)$ did not identify $\mathrm{him} /$ herself as having any religious belief (Table 2). Of these 77 adults who identified themselves as infected with the AIDS virus, 28 (36.4\%) were males and $49(63.6 \%)$ were females. These adults hailed from five states of the Southeastern Region of Nigeria (Table 3). Of those who did not endorse the AIDS virus, 56 (72.7\%) were males and 21 $(27.3 \%)$ were females. These adults also hailed form the different states of the Southeastern Region of Nigeria (Table 4). Furthermore, following

Table 2: Gender and religious orientation of the 154 participants

\begin{tabular}{lrr}
\hline Variable & $N$ & $\%$ \\
\hline Gender & & \\
Male & 84 & 54.5 \\
Female & 69 & 44.8 \\
Religious Orientation & 149 & 96.8 \\
Christians & 3 & 1.9 \\
Muslims & 1 & 0.6 \\
Traditional & 1 & 0.6 \\
Other & & \\
\hline
\end{tabular}

Table 3: Gender and state of origin of participants living with the AIDS virus

\begin{tabular}{lll}
\hline Variable & $N$ & $\%$ \\
\hline Gender & & \\
$\quad$ Male & 28 & 36.4 \\
$\quad$ Female & 49 & 63.6 \\
State of Origin & & \\
$\quad$ Anambra & 15 & 19.5 \\
Enugu & 16 & 20.8 \\
Imo & 15 & 19.5 \\
Abia & 15 & 19.5 \\
Ebonyi & 16 & 20.8 \\
\hline
\end{tabular}

Table 4: Gender and state of origin of participants not living with the AIDS virus

\begin{tabular}{lll}
\hline Variable & $N$ & $\%$ \\
\hline Gender & & \\
$\quad$ Male & 56 & 72.7 \\
$\quad$ Female & 21 & 27.3 \\
State of Origin & & \\
$\quad$ Anambra & 16 & 20.8 \\
Enugu & 15 & 19.5 \\
Imo & 17 & 22.1 \\
Abia & 15 & 19.5 \\
Ebonyi & 14 & 18.1 \\
\hline
\end{tabular}


the results, of the 77 participants who identified themselves as having the AIDS virus, 35 (45.5\%) were married, $23(29.8 \%)$ were single, $1(1.3 \%)$ was divorced, and 18 (23.4\%) was widowed. Of the 77 who did not endorse the HIV status, $47(61 \%)$ was single, $26(33.8 \%)$ was married, $1(1.3 \%)$ was divorced, $2(2.6 \%)$ was separated, and $1(1.3 \%)$ was widowed (Table 5). The health status of the respondents was also evaluated. Of the 77 participants who endorsed the AIDS virus, 11 (14.3\%) endorsed excellent health and 18 (23.3\%) reported multiple hospitalizations within one year (Table 6). Of those 77 who did not endorse the AIDS virus, 35 (45.4\%) endorsed excellent health, and $4(5.2 \%)$ reported multiple hospitalizations (Table 6). The demographic result did not indicate significant difference between males and females who reported excellent health and males and females who reported multiple hospitalizations (Table 7). The level of education of the 154 participants was classified under the following: No education, primary/secondary education, College Degree, and Graduate School. Of the 154 participants of these research, 6 (3.9\%) identified themselves as having no educational background, $86(55.9 \%)$ had primary or secondary or some vocational school, 48 (31.2\%) identified themselves as having some college education including Bachelor's degree, and 12 (7.8\%) reported some graduate school education (Table 8).

Additionally, to determine the number of participants employed, the level of employment was analyzed. Of the 154 participants, $55(33.7 \%)$ claimed being employed and $96(56.8 \%)$ reported no employment. Considering the different meanings associated with being employed and not employed in the Nigerian society, further

Table 5: Marital status of participants living and not living with the AIDS virus

\begin{tabular}{lrr}
\hline Variable & $N$ & $\%$ \\
\hline Living with HIV & 35 & 45.5 \\
Single & 23 & 29.8 \\
Married & 1 & 1.3 \\
Divorced & 0 & 0.0 \\
Separated & 18 & 23.4 \\
Widowed & & \\
Not Living with HIV & 47 & 61.0 \\
Single & 26 & 33.8 \\
Married & 1 & 1.3 \\
Divorced & 2 & 2.6 \\
Separated & 1 & 1.3 \\
Widowed & & \\
\hline
\end{tabular}

Table 6: General health status of participants living and not living with the AIDS virus

\begin{tabular}{lrr}
\hline Variable & $N$ & $\%$ \\
\hline Living with HIV & 11 & 14.3 \\
$\quad$ Excellent & 34 & 44.2 \\
1-2 Doctors' Visit/Year & 14 & 18.2 \\
Hospitalized Once or Twice & 14 & 23.3 \\
$\quad$ Multiple Hospitalizations & 18 & \\
Not Living with HIV & & \\
Excellent & 35 & 45.4 \\
1-2 Doctors' Visit/Year & 25 & 32.5 \\
Hospitalized Once or Twice & 13 & 16.9 \\
Multiple Hospitalizations & 4 & 5.2 \\
\hline
\end{tabular}

Table 7: General health status and gender of the 154 participants

\begin{tabular}{lll}
\hline Variable & $N$ & $\%$ \\
\hline General Health Status - Males & & \\
$\quad$ Excellent & 25 & 29.8 \\
1-2 Doctor's Visit/Year & 34 & 40.5 \\
$\quad$ Hospitalized Once or Twice & 14 & 16.7 \\
$\quad$ Multiple Hospitalizations & 11 & 13.0 \\
General Health Status - Female & & \\
$\quad$ Excellent & 21 & 30.0 \\
1-2 Doctor's Visit/Year & 25 & 35.7 \\
$\quad$ Hospitalized Once or Twice & 13 & 18.6 \\
Multiple Hospitalizations & 11 & 15.7 \\
\hline
\end{tabular}

Table 8: Level of the education of the 154 participants

\begin{tabular}{lrr}
\hline Variable & $N$ & $\%$ \\
\hline No Education & 6 & 3.9 \\
Primary-Secondary & 86 & 55.9 \\
College Education & 48 & 31.2 \\
Graduate Education & 12 & 7.8 \\
\hline
\end{tabular}

analysis of employment status was completed. Individuals were asked if they were independently employed or not. Of these latter question, 99 (64.3\%) reported that they worked for some other person or institution or government, 39 males $(25.3 \%)$ reported that they had their own business, 13 women $(8.4 \%)$ reported that they had their own business, and 3 individuals (1.9\%) reported no employment (Table 9).

Table 9: Employment Status of the 154 participants

\begin{tabular}{lrr}
\hline Variable & $N$ & $\%$ \\
\hline Employed & 55 & 35.7 \\
$\quad$ Yes & 96 & 56.8 \\
No & & \\
Independently Employed & 99 & 64.3 \\
$\quad$ No-Has an employer & 39 & 25.3 \\
Own Business-Male & 13 & 8.4 \\
Own Business-Female & 3 & 1.9 \\
Unemployed & \\
\hline
\end{tabular}




\section{PROCEDURE}

The investigator introduced this research to three research assistants (two males and a female), explaining the purpose of the research, the proposal and consent form. The research assistants were trained on the procedures for administering the research for one week at Nnamdi Azikiwe University. These trained research assistants are volunteers recruited from the local community based non-governmental organization (NGO) as well as academic institution in south eastern region to help in facilitating the data collection required for this study. These research assistants were provided with logistics, light refreshments and honorarium stipend on the days the questionnaires were administered. The investigator and the trained research assistants introduced the research and its purpose to the community development officer of the DFID unit at the British council's office in Enugu. The British department for international development (DFID), British council- Enugu oversea the community projects targeted to alleviate the poverty status of people living with HIV/AIDS in the rural communities of the entire South eastern region of Nigeria. The DFID community development officer then, introduced the investigator and the research assistants to the regional office of the executives of the coalition of HIV/AIDS organizations in their unit within the British councils' complex. The members of the coalition of HIV/AIDS organizations are people living with HIV/AIDS in each state in the entire south eastern region of Nigeria. The DFID staff, the investigator and the research assistants, discussed the research with the executives of the coalition of HIV/AIDS organizations and consent was obtained for the participation of their members in the research study. Access into the coalition organizations was secured through their coalition coordinators' office at the British councils' DFID office at Enugu;Enugu State; with the aid of the DFID community development staff who introduced the investigator to the executive members of the regional HIV/AIDS coalition. The coalition has a functional executive office at the DFID complex. The executive secretary of the Coalition who had a fruitful contact with the various state chairmen of their coalition, introduced the investigator to their various state chapters. The chairmen of each state coalition informed members that a researcher from an American university has come to visit them for research purpose and would like to have an interactive session with them as well. A date was scheduled to suite their major routine health care day in each state. The executive secretary accompanied the investigator to each state on the scheduled date with their coalition. In each state, the chairman of the coalition introduced the investigator to their members during the interactive session. The investigator introduced his research objectives to members. The participants had the opportunity of telling the investigator their problems. The investigator sought and obtained their informed personal consent to participate in the study. The HIV/AIDS positive participants used in the study was randomly drawn from the major coalition of HIV/AIDs related non- governmental organizations (NGOs), Community based organizations (CBOs), and Faith based organizations (FBOs)' voluntary counseling and testing (VCT) centers in each state, where people living with HIV/AIDS and those that are not, normally visit for routine Testing and health care services. The medically diagnosed HIV/AIDS positive participants and those that were not, were randomly selected on the scheduled days for routine testing and treatment in each of the five south eastern states VCT centers. The PLWHA participants belonged to various community based organizations (CBOs), faith based organizations (FBOs) and non-governmental organizations (NGOs) which differed from each other in terms of geographical locations, state of origins of members, age of members, need focus of the organization, and tenure of their existence within the state. These community based organizations (CBOs), Faith based organizations (FBOs) and Non-Governmental Organizations (NGOs) were all recognized by their various state governments and are partly sponsored by their state action committee on HIV/ AIDS, DFID, UNIFEM, UNICEF and the federal ministry of Health through the federal action committee on AIDS.

All the participants offer consent to participate in the study during the interaction sessions and responded to the consent form. The HIV/ AIDS positive participants were given light refreshment and financial honorarium by the investigator at the end of the interactive session. A battery of questionnaire was administered to the randomly selected HIV-positive participants. The state chairmen of the coalition also introduced the investigator to the medical 
personnel in charge of VCT center in the state. The personnel in charge introduce the investigator to the chairman research ethics committee of the medical center for institutional approval for the use of tested non-HIV positive participants from their center for the study. After the institutional consent had been secured, the participants' informed consent was sought and secured voluntarily because the participants were allowed to respond to the battery of tests individually. The non-positive HIV/AIDS participants were given financial honorarium for their participation. The battery of test issued to the participants accessed and explored the level of poverty status of the individual. Certain critical demographic variables such as state of origin, place of residence, among others were collected from them.

\section{Instrument}

The participants were required to respond to items on the socio-economic index of poverty questionnaires. The socio-economic index of poverty (SEIP) was developed in Nigeria (Nnedum 2006). The socio-economic index of poverty measures the extent to which an individual feels social and environmental hardship; it assesses the standard of living as well household poverty of the individual as a viable and stable index of poverty (Nnedum 2006).

To assess the poverty status of the participants, this investigator required participants to respond to the twenty items of socio-economic index of poverty questionnaire, that was designed to assess two components of poverty index in particular and the overall poverty in general. The two sub-scales are the household and standard of living dimensions. The household poverty subscale, measured by the following questions: feeding habit, sources of water and size of the household, is assessed using item 1, 2 and 3 anchored on a five-point scale. The fist item is "How many times do you eat in a day"? It is scored once $=5$, two times $=4$, three times $=3$, four times $=2$, five times and above $=1$. The second item is "What is the main source of water in your house"? $($ Tap water $=1$, bore-hole $=$ 2 , spring water $=3$, lake or ground water $=4$, river or stream $=5$ ). (Multiple choice score possible). The third item is "What is the size of your household"? It is scored $1-3=1,4-5=2,6-8$ $=3,9-11=4$ and $12-16=5$. The minimum possible score on this subscale is 3 and the maximum score is 15 . Also, Nnedum (2005) stated that a total score of 1 to 7 indicate poor household income profile (low poverty index) while a score of 7.1 and above indicate abject poor household income profile (High Poverty Index).

The standard of living subscale, measured by the form as well as the use of household facilities (toilet, water, cooking utensils and waste management) is measured by items $4-12$ anchored on "Yes or No" response scheme, only one choice is possible. The details of the household facilities indicate that toilet facility were measured by item $4,6,8,10$ and 12 ; power energy facility by item 5,7 , 9 , and 11 ; water facility by item 2 , cooking facility by item $13,15,16,17,18,19$ and 20 ; waste management facility by item 14 . Nnedum (2006) state that the minimum possible score on this subscale is 0 and the maximum score is 17 ; a score of $0-8$ indicate poor standard of living (low poverty index) while a score of 8.1 and above indicate abject poor standard of living (High poverty index). The minimum possible score for overall socio economic index of poverty scale is 03 and the maximum score is 32 . Also, an overall maximum score of 15 or less indicate low poverty level while score of 15.1 and above indicate high poverty level and the greater the score, the more the level of poverty index. The reliability co-efficient reported by Nnedum (2006) are split half $=.72$ and Eight weeks interval testretest $=.88$ and alpha $\mu=.78$. In addition, Nnedum (2006) obtained a concurrent validity co-efficient of 86 by correlating SEIP with the economy scale (Verga 1997).

Based on the scoring from the manual (Nnedum 2006) a score of 15 indicate low poverty level and any score above 15.1 indicates a high poverty level on the socio-economic index of poverty main scale.

\section{Hypotheses}

Hypothesis I: The people living with HIV/ AIDS will experience higher levels of poverty than the non infected HIV-negative people.

Hypothesis II: The people living with HIV/ AIDS will experience higher levels of household poverty than the non infected HIV-negative people.

Hypothesis III: The people living with HIV/ AIDS will experience higher levels of poor standard of living than the non infected HIVnegative people. 


\section{Statistical Analysis}

This study is a comparative study that employed multivariate analysis that utilizes descriptive statistics, frequencies, Multivariate Analysis of variance (MANOVA). All data were analyzed utilizing the statistical program for the social sciences (SPSS).Descriptive analysis provided general information about the subject population. MANOVA allowed for compares between the groups on poverty.

\section{RESULTS}

\section{Pervasiveness of Poverty among PLWHA}

Hypothesis 1: The people living with HIV/ AIDS will experience higher levels of poverty than the non infected HIV-negative people. Using MANOVA, individuals' poverty experience is significantly $F(1,153)=05.76, p<.004$ impacted by whether or not an individual is HIV positive or HIV negative. On the poverty main scale used for this study, People living with HIV/AIDS obtained a mean score of 18.44 and a standard deviation of 3.24 while people not infected with HIV virus obtained a mean score of 16.96 and with a standard deviation 2.31, (see Table11 and 12 for mean scores). Based on the scoring of the results of the stigma scale, the higher the score, the greater is the poverty experience. In this study, the variables in the poverty sub-scale were analyzed using MANOVA to test the second and third hypotheses.

Hypothesis 11: The people living with HIV/ AIDS will experience higher levels of household poverty than the non infected HIV-negative people. MANOVA results show a statistically insignificant difference between PLWHA and those that are not, on household poverty, with $\mathrm{F}$ $(1,153)=.772, p<.487$.On the household sub-scale of the poverty scale used for this study, People living with HIV/AIDS obtained a mean score of 11.16 and a standard deviation of 02.16 while the HIV negative, people not infected with HIV virus, has a mean of 10.81 with a standard deviation of 2.62, (see Table11 and 12 for mean scores).

Hypothesis 111: The people living with HIV/ AIDS will experience higher levels of poor standard of living than the non infected HIVnegative people. MANOVA results show a statistically significant difference between PLWHA and those that were not infected with
Table 10: Summary of results of univariate test statistics for the dependent variables.

\begin{tabular}{lrrr}
\hline Variable & $M S$ & $F$ & Sig. \\
\hline Poverty & 45.586 & 5.756 & .004 \\
Standard of living & 63.656 & 23.668 & .000 \\
Household poverty & 04.168 & .722 & .487 \\
\hline Note. $P<.05$
\end{tabular}

Note. $P<.05$

Table 11: Means and Standard deviations for the dependent variables of people living with HIV/AIDS.

\begin{tabular}{lcccc}
\hline Variables & $M$ & $S D$ & $C I$ & $N$ \\
\hline Poverty & 18.4416 & 3.23831 & $17.81-19.07$ & 77 \\
$\begin{array}{c}\text { Standard of } \\
\quad \text { living }\end{array}$ & 07.6232 & 1.82842 & $07.26-07.99$ & 77 \\
$\begin{array}{c}\text { Household } \\
\text { poverty }\end{array}$ & 11.1579 & 2.16057 & $10.59-11.67$ & 77 \\
\hline
\end{tabular}

Table 12: Means and Standard deviations for the dependent variables of people not infected with AIDS/HIV.

\begin{tabular}{lcccc}
\hline Variables & $M$ & $S D$ & $C I$ & $N$ \\
\hline $\begin{array}{l}\text { Poverty } \\
\begin{array}{l}\text { Standard of } \\
\text { living }\end{array}\end{array}$ & 16.9605 & 2.30617 & $16.30-17.57$ & 77 \\
$\begin{array}{c}\text { Household } \\
\text { poverty }\end{array}$ & 10.8182 & 2.61940 & $10.28-11.36$ & 77 \\
\hline
\end{tabular}

the HIV virus on poor standard of living, with $\mathrm{F}$ $(1,153)=23.67, \mathrm{p}<.000$.

On the poor standard of living sub-scale used for this study, People living with HIV/AIDS obtained a mean score of 07.62 and a standard deviation of 1.83 while people not infected with HIV virus obtained a mean score of 05.80 and with a standard deviation of 1.42 , (see Table11 and 12 for mean scores).Based on the scoring of the results of the stigma scale, the higher the score, the greater is the poverty experience.

\section{DISCUSSION}

The primary purpose of this study is to examine the pervasiveness of poverty among people living with HIV/AIDS, in South Eastern region of Nigeria. The major variables measured in this study were poverty. Poverty measures explain the impact of economic factors such as Poverty, poor standard of living and household poverty implications of people living with HIV/ AIDS in South Eastern region of Nigeria. Consistent with the hypotheses that the people living with HIV/AIDS will experience greater levels of poverty, household poverty and poor standard of living than the non infected HIV-negative 
people, the findings from table 1, 2, 3 indicated that there is significantly greater pervasiveness of poverty among the PLWHA than those that are not infected. Research suggests that HIV/ AIDS negatively impacts households' income and expenditure, increase income inequality, reduces a nation's productivity, and governments' ability to implement poverty reduction strategies (Masha 2004; Nnedum 2006). Thus the hypotheses that people living with HIV/AIDS will experience greater pervasiveness of poverty, household poverty and poor standard of living than those not infected were confirmed. The results were consistent with previous empirical studies (Caldwell and Caldwell 1987 ; Cornwell 2002; Glynn et al. 2003; Smith 2007) and Africa in general (Campbell et al. 2007 ; Foster 2007 ; Mendenhal et al. 2007; Merter and Haller 2007 ; Solojee et al. 2007) that suggests the pervasiveness of poverty among PLWHA and explore its' effect on the life of people living with HIV/AIDS on one hand ; and the way poverty alienate, mitigate, subjugate and negates the ability of people living with HIV/ AIDS from seeking voluntary health care services, earn income or actualize themselves on the other hand.The finding is in line with several research and reports (World Bank 1997; Federal Ministry of Health Report of HIV - Sero Sentinel Survey 2003, 2005 ; Foster 2007; Smith 2007 ) that indicated that the majority of people living with HIV/AIDS are poor and had less access to available health care information. It is plausible that Poverty, pervasively abject poverty(Nnedum 2006), affecting people living with HIV may be understood through studies of both social and economic capital (Foster 2007), economic impact of individual case,(Odujole 2004), macroeconomic impact (Hancock et al. 1996), reduction in nations productivity (Whiteside 2000; UN global impact 2007), Nigerian government effort to implement poverty reduction strategy (Soludo 2005), and monetary provincial standard of household (Lachaud 2007), household poverty and standard of living (Nnedum 2006). Recent finding suggests that it is important to consider the economic dynamics of poverty and HIV illness on human health conditions of people living with HIV/AIDS and how these might affect the ability of individuals to seek and maintain their health status (Rajaraman et al. 2006) because it has become important to understand the structural and economic barriers preventing better health outcomes amongst the HIV infected, the majority of whom are impoverished (Pronyk et al. 2001 ; McCoy et al. 2005). Again macro-economic impacts of HIV/AIDS are likely to be associated with poverty at the household level (Hancock et al. 1996). Recent study in Uganda implicated poverty, background poverty and limited health services in rural regions as the barriers to adherence to antiretroviral therapy (Weide et al. 2006). The socio-economic index of poverty (SEIP) measures the extent to which an individual feels social and economic hardship that assess the standards of living of the individual as a viable and stable index of poverty (Nnedum 2005). It is apparent that socio-economic status of people in sub-Saharan Africa is the most viable measure of individuals standard of living as well as their poverty status (Nnedum 2005, 2006) because in most developing economies where social security is less available, the unstable economic environment and chronically complex unemployment make the use of the socio-economic status measure much more suitable (Nnedum 2006) for assessing the poverty status of individuals in accordance with the existing literature (Fourie and Schonteich 2001 ; Waterson 2003; Greener et al. 2004) Thus, while abundant but contradictory studies on poverty employed macro-economic measure to elaborate the impact of HIV/AIDS on poverty status of people living with HIV/AIDS (Hancock et al.1996), few studies attempt to discuss poverty as a predictor variable of HIV/ AIDS disease, other studies explore poverty as a criterion measure of HIV/AIDS epidemic, this study discuss poverty in terms of the household poverty and standard of living of people infected as well as affected by HIV disease.

To investigate the pervasiveness of poverty among PLWHA the survey questions assess the status of the individuals family feeding habit, sources of basic water to the household, the size of the household and the individuals' standard of living; the availability of convenience facilities, the sources of energy utilization in the household, available sources of fuel energy for staple food preparation, and available sources of waste management in the household. Further explanation of the findings indicate that poverty is more pervasive among people living with HIV/AIDS (X: 18.44) than those that are not infected (X: 16.96) in South Eastern Nigeria with $F(1,153)=$ $5.76, \mathrm{p}=.004$. The people living with HIV/AIDS experience very much severely poor and threatening standard of living (X: 7.62) than non- 
infected (X: 5.8) people living in South Eastern Nigeria, with $F(1,153)=23.67, p=.000$.It is apparent that economic constraints has separated Igbo people from the cultural responsibilities of extended family safety net and financial hardship had pauperized households of people living with HIV/AIDS (X: 11.15) as much as families of other people (X:10.81) living in South Eastern Nigeria, with $\mathrm{F}(1,153)=.722, \mathrm{p}=.487$. These results suggest that poverty is pervasive in the life of individuals living with HIV/AIDS in particular. HIV/AIDS decreases the nutritional intake of staple food, decreases government efforts to provide stable water supply, and increase the number of dependent households. Again, abject poverty is very much severely pervasive among people living with HIV/AIDS, the poverty index is severely threatening as the people living with HIV/AIDS appear to be the pervasively poor.And pauperized people living with HIV/AIDS does not have access to prevailing information describing available health care services. One obvious implication is not only that people living with HIV/ AIDS experience higher levels of severely pervasive poverty, but the poverty conditions their psyche and makes them to be ignorant, or lack knowledge of, or have less access to, information about available basic health care (Ezeokana and Nnedum 2007). Specifically, the household dimension reveals that people living with HIV/AIDS who are from poor households, or impoverished home, do not have access to, and do not seek for antiretroviral medication (Nnedum and Ezeokana 2007). The implication is that people living with HIV/AIDS in South Eastern Nigeria have severely high index of poverty, with means in overall poverty of 18.4 , household subscale of 11.15 and standard of living subscale of 7.6 respectively. Thus, individual who are living with HIV/AIDS are pervasively poor. Poverty is a disease. The Poor does not have access to clean staple water and have large family that are living in overcrowded squalors; does not have ability to seek antiretroviral medication. The abjectly poor people are more powerless and lack the power of information that provides basic knowledge of available health care services that leads to HIV testing and possibly antiretroviral treatment.

To the people living with HIV/AIDS, the consequence of poverty is glaring. Poverty emasculates the cognitive thoughts and rational awareness of the PLWHA. It is plausible that poor people are not aware of the clinically medical opportunities to explore to ascertain their seroviral load for the infected or HIV status for others (Nnedum and Ezeokana 2007). Poverty restrains limits, and disillusions, the individual from access to knowledge of HIV testing (Nnedum and Ezeokana 2007). The lack of knowledge of test for HIV infection determines the inability of the individual to avail oneself of the opportunity for free HIV testing and counseling services among people in the South Eastern Nigeria.

\section{RECOMMENDATIONS}

Any viable attempt to address HIV/AIDS epidemics must equally address poverty because this study show clearly that HIV/AIDS patients differed from non HIV/AIDS patients in their poverty level and those with HIV/AIDS positive are poorer than those without. There is need to arm the people with small scale business .This will not only alienate their poverty but will also enhance their social relevance in their community. The poor people appears to be having more problem with HIV/AIDS than the rich because the rich people who are more educated have access to media information, and availability literature on HIV/AIDS. The access to information brings the knowledge of HIV/AIDS. This group of people would be more likely to avail themselves of the opportunity for routine HIV/AIDS test and counseling. HIV/AIDS testing determines their access to antiretroviral treatment that in turn enables them to access health care services for their care, coping and management of their conditions. But the poor cannot afford all these. One of the Ways to manage HIV/AIDS for the poor who are living with HIV/AIDS is through free and affordable antiretroviral therapy. Awareness and enlightenment should be brought lower from the level of media (radio and TV) to the level town criers, community meetings and Faith based organization announcements. There was lack of employment desirability benefits for PLWHA in Nigeria. There is need to enact welfare package that protect and sustain the work of PLWHA in Nigeria.

\section{Limitations of the Current Study}

There were extensive limitations of the current study that should be considered. The use of people living with HIV/AIDS residing in selected 
urban cities of the South Eastern Region of Nigeria was relevant to the design of the study, apparently the south eastern region of Nigeria is one of the six geo-political zones of Nigeria, but the findings of the study on PLWHA in this region do not represent that of PLWHA in the entire country because of the small sample size; this factor limits the generalizability of the results to the Nigerian population, taken as a whole. Nigeria is a multi-cultural, multi-linguistic, multi-ethnic country with diverse, values, beliefs, religions, meaning attached to illness and disease, as well as legally asymmetrical laws and policies. The country's multi-cultural attitudes tend to limit, to a large extent, the generalizability of poverty experience in the entire population.

Furthermore, this study did not address the cause of poverty in the South Eastern Region of Nigeria because the focus was on household and poor standard of living only. Considering the Nigerian's fragile, emerging economy and the pandemic spread of the AIDS/AIDS, it is possible to assume that poverty exacerbates the spread of the AIDS virus and results from the spread and hence the pervasiveness of poverty among PLWHA.

\section{SUGGESTIONS FOR FUTURE RESEARCH}

Limitations of the current study raise several issues that could be explored in future research. It would be intellectually stimulating to explore the adult PLWHA'S level of poverty experience in other parts of Nigeria and among Nigerian adult PLWHA from the rural area of South Eastern Region of Nigeria, but residing in the rural area. The result of a scientific study on poverty and the spread of the HIV/AIDS disease would provide significant research information in planning effective HIV/AIDS prevention strategies and intervention in Nigeria and in other resource-poor countries.

\section{CONCLUSION}

In conclusion, the present study provides valuable and important research information on the economic, and social experience of adults living with HIV/AIDS residing in selected states of the South Eastern Region of Nigeria. The finding of the study is valuable to the field of psychotherapy, clinical, economic, and behavioural psychology. This study provides better understanding of poverty experience as it impacts adult people living with HIV/AIDS residing in South Eastern Nigeria.

\section{REFERENCES}

Bamett T, Whiteside A 2002. AIDS in the $21^{\text {st }}$ Century: Disease and Globalization. New York: Machmillan. Bjorkman H 2002 . HIV/AIDS and Poverty Reduction Strategies. From http://www.undp.org (Retrieved August 5, 2004)

Bond V, Chase E, Aggleton P 2002. Stigma, HIV/AIDS and Prevention of Mother -to-child transmission in Zambia. Evaluation and Programme Planning, 25: 347-356.

Brown L, Trujillo L, Macintyre K 2001. Interventions to reduce HIV/AIDS Stigma: What have we learned? Horizons Program, Tulane University.

Bureau for Global Health 2001. Country Profile: HIV/ AIDS in Nigeria. From web site http:www.usaid.gov (Retrived December14, 2007)

Bureau of Global Health 2003. Country Profile: HIV/ AIDS in Nigeria. From http://www.usaid.gov/pop health/aids/countries/africa/nigeria.html (Retrieved July 6, 2004)

Caldwell J, Caldwell P 1987. Perceived male sexual Needs and male sexual behaviour in Southwest Nigeria . Social Science and Medicine, 44(8): 1195 - 1207.

Campbell C, Nair Y, Maimane S, Nicholson J 2007. Dying Twice: a multi-level model of the roots of AIDS Stigma in two South African Communities. Journal of Health Psychology, 12(3): 403-16.

Castro R, Orzco E, Manca M C, Hernandez JJ , Aggleton P 1998. AIDs-related illness trajectories in Mexico: findings from a qualitative study in two marginalized communities. AIDs Care, 10(5): 583-598.

Catholic Agency for Overseas Development. 2003. HIV, poverty and debt. From http://www.cafod.org.uk/ policy_and analysis/policypapers/hivaids/hiv poverty_and_debt (Retrieved August 21, 2004)

Chacham AS, Mala MB, Greco M, Silva AP, Greco DB 2007. Automony and Susceptibility to HIV/AIDS among Yung women living in a slum in Belo Horizonte, Brazil. AIDS Care, 19(1): 12-22.

Cluver L, Gardner F 2007. Risk and Protective factors for psychological well-being of children orphaned by AIDS in Cape Town: a qualitative study of children and caregivers' perspectives. AIDS Care, 19(3): 318325

Cornwell A 2002. Spending power: Love, Money, and the reconfiguration of Gender Relations in Ada-Odo, South Nigeria, Amerian Ethnologist, 29(4) :963-980.

Ezeokana OJ, Nnedum OAU 2007. Influence of Economic hardship on social interaction and disclosure help seeking behaviuor. Nigerian psychologist: An International journal, 2(1): $19-26$.

Federal Ministry of Health Nigeria (FMHN) 2005. Technical reports on 2005 National HIV/Syphilis Sentinel survey among pregnant women attending antenatal clinics in Nigeria, Abuja: Nigeria.

Federal Ministry of Health Nigeria (FMHN) 2004. Technical reports on 2003 National HIV/Syphilis Sentinel survey among pregnant women attending antenatal dinies in Nigeria, Abuja: Nigeria. 
Federal Ministry of Health Nigeria (FMHN) 2003. National HIV/AIDS And Reproductive Health Survey. Abuja: Nigeria.

Foster G 2007. Under the radar: Community safety nets for AIDS -affected households in sub-Saharan Africa. AIDS Care, 19: 54-63.

Fourie P, Schoneteich M 2001. Africa's new security Threat: HIV/AIDS and human security in Southern Africa. African Security Review, 10, 4. From http:www.iss.co.za/Pub/ASR/10No4/Fourie.html (Retrieved July 25, 2004)

Gilmore MR, Morrison DM, Richey CA, Balassone ML, Gutierrez L, Farris M 1997. Effects of a Skill-based Intervention to Encourage Condom Use among High Risk Heterosexual Adolescents. AIDS Education and Prevention, $9: 22-43$

Glynn JR, Carael M, Buve A, Musonda RM, Kahindo M 2003. HIV Risk in relation to marriage in areas with High prevalence of HIV Infection. Journal of acquired Immune Deficiency Syndromes, 33(4): 526-535.

Greener R, JuanPeblo G, Benjamin J, Taghreed A, Bertozzi SN, Tan-Torress T 2004. Achieving the WHO/ UNAIDS antiretroviral treatment 3 by 5 goal: What will it cost?. Lancet, 364: 63-64.

Hancock J, Nalo D, Aoko M, Materials R, Clark H 1996. The macroeconomic Impact of HIV/AIDS in Kenya. AIDS Analysis Africa, 7: 1.

Hawkers C, Ruel M 2005. The Links between agriculture and health: an intersectional opportunity to improve the health and livelihoods of the poor. Bulletin of the world Health Organization, 84: 12.

HIV/AIDS Emergency Action Plan [HEAP] 2001. Report from National Action Committee on HIV/AIDS in Nigeria (NANA). From http://www.nigeria-aids.org/ pdf/heap.pdf (Retrieved June 6, 2004)

Human Development Report Nigeria 2004. Official Home Page of Human development New York. From http://en.wikipedia.org/wiki/Human_Development_ Index (Retrieved June 6, 2007)

Human Development report Nigeria 2003. Official Home page of Human Development New York. From http:/ /en.wikipedia.org/wiki/Human_Development_Index (Retrieved 18, October, 2006).

Human Development report Nigeria 2000. Official Home page of Human Development New York. From http:/ /en.wikipedia.org/wiki/Human_Development_Index (Retrieved 1, Decmber, 2001).

Kaiser Family Foundation 2003.HIV/AIDS: Nigeria Profile. From Henry J. Kaiser Family Foundation of South Africa Web site<http://www.fhi.org (Retrieved August 4, 2004).

Kaiser Family Foundation 2007. HIV/AIDS: Nigeria Profile. From Henry J. Kaiser Family Foundation of South Africa Web site<http://www.fhi.org (Retrieved August 4, 2007).

Lachaud JP 2007. HIV Prevalence and Poverty in Africa: Micro-and Macro-econometric evidences applied to Burkina Faso. Journal of Health Economics, 26(3): 483-504.

Lazzarini Z 2002. HIV and the law: Integrating law, policy, and social epidemiology. Journal of Law, Medicine, and Ethics, (in press)

Masha G 2004. Psyched out. New Republic, 23, 26-28: 18-19.
McCoy D, Chopra M, Loewenson R, Aitken JM, Ngulube T, Muulo A, Ray S, Kureyi T, Ijumba P, Rowson M 2005.Expanding access to antiretroviral therapy in sub-Saharan Africa: Avioding the pitfalls and dangers, capitalizing on the opportunities. American Journal of Public Health, 95(1): 18-22.

Mendenhall E, Muzizi L, Stephenson R, Choba E, Ahmed Y, Haworth A, Allen S 2007. Properly Grabbing and will writing in Lusaka, Zambia: An Examination of Wills of HIV-Infected Cohabiting Couples. AIDS Care, 19(3): 369-374.

Merter S, Haller T, 2007. Culture, Changing Divelihood and HIV/AIDS Discourse: reframing the Institutionalization of fish-for-sex exchanges in the Zambian Kafue Flats. Culture Health, and Sexuality, 9(1): 69-83.

Nnedum OAU 2006. Evaluation of HIV-AIDS Prevention - Reduction Related Services of Anambra State Action Committee on HIV-AIDS (ANSACA) in Nigeria. Review of Behavioural Perspectives, 2(3): 24-32.

Nnedum OAU 2005. Standardization of the Socioeconomic index of poverty (SEIP). Nigerian Psychologist: An international Journal, 1(1): 11-21.

Nnedum OAU ,Ezeokana JO 2007. Influence of perceived self efficiency on sexual negotiation and condom use. Interdisciplinary Journal of Contemporary Studies, 1(1): 7-13.

Noor kFT, Lov SD, McElmurry BJ 1996. Aids Awareness and Knowledge Among Botswana Women: Implications For Prevention Programs. Health Care for Women International, 17: 133-148.

Nosyk B, Li Y, Sun HI, Anis H 2007. The effect of homelessness on hospitalization among patients with HIV/AIDS. Aids Care, 19(4): 546-553.

Odujole L 2004. Role of RH Practitioners in Management of HIV/IDS In the Workplace. Proceeding of the chartered Institute of Personnel Management of Nigeria. December to-7, 2004.

Pronyk P, Kim J, Porter J 2001. Whose Priorities: A Response to the Issue of antiretrovorals in Africa. Tropical Medicine and International Health, 6: 575577

Rajaraman D, Russell S, Heymann J 2006. HIV/AIDS, Income Loss and Economic Survival in Botswana. AIDS Care,18(7): 656-662.

Rennie S, Behets F 2006. Desperately Seeking Targets: The ethics of routine HIV testing in Low-Income Countries. Bulletin of the World Health Organization, 84(1): 52-57.

Saloojee H, Mdayer TJ, Garenne ML, Kahn K 2007. What is new? Investigating risk factors for severe childhood Malnutrition in a high HIV prevalence South African Setting. Scandinavian Journal of public Health, 69: 96-106.

Smith DJ 2007. Modern Marriages, Men's Extramarital Sex, and HIV Risk in Southeastern Nigeria. American Journal of Public Health, 97, 6: 997-1005.

Smith DJ 2002. Man No Be Wood: Gender and Extramarital Sex in Contemporary Southeastern Nigeria. Ahfad Journal, 19(2): 4-23.

Smith DJ 2001. Romance, Paranthood and Gender in a modern Africa Society. Ethnology, 40(2): 129-151.

Soludo CC 2005. National Economic Empowerment and development strategy [NEEDS] technical report. 
Nigerian Printing and Minting Co-Operation, Abuja: Nigeria.

Stillwaggon E 2001. AIDS and poverty in Africa: The nation. From http://www.thenation.com/doc.mhtml? $1=2001052$ ands=stillwaggon $($ Retrieved July 25, 2004)

Takahashi LM 1998. Homelessness, AIDS, and Stigmatization: The NIMBY Syndrome in the United State at the end of the Twentieth Century. New York: Oxford University Press.

UN Global Compact 2007. The global impact of HIV / AIDS. From $<$ http://www.unglobalcompact.org (Retrieved July 25, 2008).

UNAIDS 2004. Sub-Saharan Africa: Regional HIV and AIDS Estimates, End 2003. From http:// www.unaids.org/en/geographical (Retrived August $9,2005)$.

Verga CA 1997. The Condom Condrum: Barriers to condom use Among Commercial Sex Workers in Durban, South Africa. Journal of Reproductive Health, 1(1): $74-88$.

Waterson T 2003.Inequity in child Health as a global issue. Pediatrics, 112(3): 739-740.

Weidle P, Wamai N, Solberg P, Liechty C, Sendegala S, Were W, Mermin J, Buchacz K, Behumbuze P, Ranson RL, Bunnell R 2006. Adherence to antiretroviral therapy in a home-based AIDS care programme in rural Uganda. Lancet, 368: 1587-94.

Whiteside A 2000. AIDS and the private sector. AIDS Analysis Africa, 10: 1-6.

Williams G, Ray S 1993.Work against AIDS: Workplacebased AIDS initiatives in Zimbabwe(strategies for Hope series No.8). Action Aid. Kenya: AMREF.

World Bank 1997.Confronting AIDS: Public Priorities in a Global Epidemic. New York: Oxford University Press. 